\title{
Suplementasi Seng Untuk Pencegahan Penyakit Infeksi
}

\author{
Aryu Candra
}

\section{Bagian Gizi, Fakultas Kedokteran, Universitas Diponegoro}

\begin{abstract}
ABSTRAK
Seng diperlukan oleh manusia dan hewan untuk melaksanakan fungsi fisiologis, seperti pertumbuhan, kekebalan tubuh, dan reproduksi. Defisiensi seng menyebabkan anoreksia, gangguan pertumbuhan, dermatitis, gangguan pengecapan, dan hipogonadisme. Prevalensi defisiensi seng pada balita di Indonesia belum diketahui dengan pasti, namun diperkirakan cukup tinggi mengingat pola makan balita di Indonesia yang belum sesuai dengan anjuran pedoman gizi seimbang. Dari hasil penelitian awal pada tahun 20 diketahui bahwa asupan seng pada balita di wilayah kelurahan Jomblang kota Semarang $30 \%$ termasuk dalam kategori kurang.

Seng juga sangat berperan dalam proses pertumbuhan, perkembangan fungsi kognitif, dan imunitas.. Banyak penelitian yang sudah membuktikan bahwa defisiensi seng dan zat besi menyebabkan gangguan pertumbuhan dan fungsi kognitif. Defisiensi seng juga dapat menurunkan jumlah dan ukuran sel-sel imun, terutama sel T sehingga kekebalan tubuh akan menurun yang menyebabkan balita menjadi lebih mudah terserang penyakit infeksi.

Pola makan balita di Indonesia sebagian besar hanya terdiri atas makronutrien yaitu karbohidrat, protein, dan lemak. Hal ini yang menyebabkan munculnya defisiensi mikronutrien pada balita. Oleh karena itu diperlukan suplementasi mikronutrien seperti seng untuk mengatasi defisiensi seng pada balita sehingga dapat meningkatkan imunitas dan mencegah infeksi.
\end{abstract}

Kata kunci: Seng, Infeksi, Balita 


\section{PENDAHULUAN}

\section{Infeksi}

Infeksi adalah masuk dan berkembangbiakanya mikroorganisme ke dalam tubuh dan menimbulkan gejala dan tanda kloinis. Sistem imunitas atau sistem kekebalan tubuh sangat diperlukan seseorang untuk menjaga dari serangan penyakit infeksi dan meningkatkan kualitas hidup. Sistem imun dikategorikan menjadi system imun bawaan dan system imun didapat. Sistem imun bawaan diperoleh sejak lahir sedangkan system imun didapat diperoleh setelah terpapar dengan agen penyebab penyakit. Di dalam system imun bawaan, yang paling berperan adalah makrofag karena berfungsi sebagai fagositosis yang membunuh berbagai macam mikroorganisme yang masuk ke dalam tubuh. Makrofag berasal dari sel darah putih (leukosit). Leukosit berdiferensiasi menjadi berbagai macam sel yang berperan penting dalam system imunitas.

Jumlah sel darah putih di dalam darah normal adalah 4000-11000/ml. Peningkatan jumlah leukosit menandakan adanya infeksi atau proses inflamasi. Selain meningkat, jumlah leukosit dalam darah dapat mengalami penurunan yang disebabkan karena berbagai faktor. Penurunan jumlah leukosit disebut juga sebagai leukopenia, merupakan kondisi yang berbahaya karena dapat melemahkan system kekbalan tubuh. Salah satu faktor yang menyebabkan penurunan jumlah leukosit adalah defisiensi zat gizi seperti vitamin dan mineral. Seng dan zat besi merupakan zat gizi yang dapat meningkatkan system kekebalan tubuh karena kedua zat ini merupakan salah satu unsur pembentuk komponen-komponen system kekebalan tubuh seperti sel-sel darah baik sel darah merah dan sel darah putih. Defisiensi seng dan zat besi akan menurunkan system imunitas sehingga meningkatkan kejadian penyakit infeksi pada balita.

Ketika terjadi infeksi, maka kebutuhan akan zat-zat gizi yang berhubungan dengan sistem kekebalan tubuh akan meningkat. Mikronutrien seperti seng dan zat besi diperlukan untuk melawan penyakit infeksi. Pada saat terjadi infeksi, terjadi perubahan distribusi seng yang merupakan bagian dari acute phase response. Terjadi pengaliran seng dari sirkulasi ke dalam sel, terutama sel hati, sumsum tulang belakang, dan timus. Timus menghasilkan hormon timulin yang berfungsi dalam proses maturasi dan diferensiasi sel T. Hormon timulin juga berfungsi sebagai efek anti inflamasi yang dapat menurunkan TNF- $\alpha$, IL-1 $\beta$, dan IL-6 yang menyebabkan kerusakan paru karena pnemumonia.

\section{Seng}


Seng ditemukan di semua organ dan jaringan (terutama intraseluler) dan dalam cairan tubuh. Fungsi seng antara lain berperan dalam pertumbuhan dan pembelahan sel, antioksidan, perkembangan seksual, kekebalan seluler dan humoral, adaptasi gelap, pengecapan serta nafsu makan. Seng terutama dibutuhkan untuk proses percepatan pertumbuhan; hal ini bukan saja disebabkan karena efek replikasi sel dan metabolisme asam nukleat, tetapi juga sebagai mediator dari aktifitas hormon pertumbuhan. Pertumbuhan mencit yang diberikan diet rendah seng akan terhenti dalam 24 jam sebagai akibat menurunnya aktifitas hormon pertumbuhan.. Peranan terpenting seng bagi mahluk hidup adalah pada pertumbuhan dan pembelahan sel. Dengan demikian seng berperan penting dalam sintesa dan degradasi dari karbohidrat, lemak, protein, asam nukleat dan pembentukan embrio.

Kandungan seng dari makanan bervariasi, sumber yang sangat baik dari seng adalah daging merah (terutama daging organ) dan makanan laut (terutama tiram dan moluska). Produk hewani diperkirakan menyediakan antara $40 \%$ dan $70 \%$ seng dikonsumsi oleh kebanyakan orang di Amerika Serikat. Sumber hewan yang baik lainnya dari seng termasuk unggas, babi, dan produk susu. Biji-bijian dan sayuran (berdaun dan akar) merupakan tanaman sumber yang baik dari seng. Buah-buahan dan olahan sereal memiliki kandungan seng yang sedikit. Sumber tanaman tidak hanya memiliki kandungan seng yang lebih rendah, tetapi seng dari tanaman juga diserap pada tingkat lebih rendah dari seng dari daging.

Seperti besi, seng perlu dihidrolisis dari asam amino dan asam nukleat sebelum dapat diserap. Seng diyakini dibebaskan dari makanan selama proses pencernaan, kemungkinan besar oleh protease dan nucleases di lambung dan usus kecil. asam klorida juga tampaknya memainkan peran penting dalam pencernaan dan penyerapan seng. Antasida, H2 receptor blockers (seperti Zantac, Tagamet, atau Pepcid), dan blocker pompa proton (seperti Prevacid atau Prilosec) meningkatkan $\mathrm{pH}$ lambung, sehingga penyerapan seng menurun. Peran asam lambung pada pencernaan dan penyerapan seng belum dijelaskan tetapi mungkin berkaitan dengan gangguan hidrolisis seng dari asam nukleat atau asam amino, perubahan pada keadaan ionik seng, atau perubahan dalam membran enterosit yang mempengaruhi penyerapan seng.

Lokasi utama penyerapan seng dalam saluran pencernaan adalah usus kecil proksimal, kemungkinan besar jejunum. Namun, kontribusi relatif dari setiap segmen dari usus kecil (duodenum, jejunum, dan ileum) terhadap penyerapan seng secara keseluruhan belum ditunjukkan. Seng diserap ke enterocyte dengan proses carrier-mediated, dengan intake seng yang rendah akan diserap lebih efisien daripada intake seng yang lebih tinggi. Sebuah pembawa protein yang disebut Zrt- dan Irt-seperti protein (ZIP)4 dianggap sebagai transporter utama 
seng melintasi membran brush border dari enterocyte. ZIP dianggap tidak memerlukan ATP, tetapi mekanisme transportasi tidak digambarkan dengan jelas. Namun, mutasi di ZIP4 diketahui menyebabkan gangguan enteropathica acrodermatitis. Kondisi ini ditandai dengan penyerapan seng yang sedikit dan secara klinis dimanifestasikan oleh lesi kulit (yang sering terinfeksi), terutama pada wajah, lutut, dan bokong; gangguan pertumbuhan; dan konsentrasi plasma seng rendah, yang mewakili tanda-tanda dan gejala defisiensi seng. dosis tinggi seng dapat diserap dengan cara lain, terutama dengan difusi atau paracellularly, biasanya memperbaiki gejala. transporter lain, DMT1 (divalen mineral transporter 1, tetapi juga kadang-kadang disebut divalen kation transporter-DCT- dan selanjutnya disebut DMT1), pernah dianggap terlibat dalam penyerapan seng di brush border. Namun, meskipun seng tampaknya mengatur ekspresi DMT1 mRNA, DMT1 transporter tidak muncul untuk mengangkut jumlah yang signifikan dari seng ke dalam sel-sel usus.

Selain transportasi carrier-mediated, difusi pasif dan penyerapan seng parasellular juga diduga terjadi dengan asupan seng yang tinggi. Penelitian telah menunjukkan bahwa umumnya penyerapan seng bervariasi dari sekitar $10 \%$ sampai 59\%; pada asupan tinggi seng maka penyerapan berkurang, dan pada asupan seng rendah maka penyerapan meningkat. Seng diasup dalam bentuk cair dan pada jumlah yang lebih besar dari $20 \mathrm{mg}$, maka penyerapan tidak berjalan dengan baik.

Seng ditemukan dalam berbagai bentuk suplemen (tablet oral, lozenges, dan semprotan), termasuk seng oksida, seng sulfat, seng asetat, seng klorida, dan seng glukonat. Setiap bentuk berbeda pada jumlah seng yang tersedia dan yang terserap. Seng gluconate, misalnya, terdapat sekitar 14,3\% seng, sedangkan seng sulfat terdapat $23 \%$ seng, dan seng klorida terdapat $48 \%$ seng. suplemen seng harus dikonsumsi saat perut kosong, tanpa secara bersamaan menelan suplemen mineral lainnya. iritasi lambung adalah efek samping yang umum.

Beberapa kelompok penduduk, terutama orang tua dan vegetarian, ditemukan mengkonsumsi jumlah seng yang kurang dari kebutuhan. Kondisi yang berhubungan dengan peningkatan kebutuhan asupan termasuk alkoholisme, penyakit kronis, stres, trauma, operasi, dan malabsorpsi. Tanda dan gejala defisiensi seng adalah hambatan pertumbuhan (respon awal untuk defisiensi seng pada anak-anak disebabkan oleh pembelahan sel yang tidak memadai namun diperlukan untuk pertumbuhan), kelainan skeletal dari pengembangan gangguan tulang rawan epifisis, sintesis kolagen rusak atau silang, penyembuhan luka yang buruk, dermatitis (terutama di sekitar lubang tubuh), tertunda kematangan seksual pada anak-anak, hypogeusia (menumpulkan dari indera perasa), alopecia 
(kerontokan rambut), fungsi kekebalan tubuh terganggu, dan sintesis protein terganggu.

Asupan yang berlebihan dari seng dapat menyebabkan keracunan. Toksisitas akut dengan 1 sampai $2 \mathrm{~g}$ seng sulfat (225-450 $\mathrm{mg}$ seng) dapat menghasilkan rasa logam, mual, muntah, nyeri epigastrium, kram perut, dan diare berdarah. Asupan seng secara kronis dalam jumlah sekitar $40 \mathrm{mg}$ (lebih rendah bagi sebagian orang) menyebabkan defisiensi tembaga. Batas atas asupan seng yang ditoleransi telah ditetapkan pada $40 \mathrm{mg}$ per hari berdasarkan interaksi ini dengan tembaga.

Seng berinteraksi secara tidak langsung dengan spesies oksidan dengan cara menstabilkan membran sel yang rentan dan menjadi kofaktor enzim antioksidan pada superoxide dismutase dan metaloprotein yang merupakan pemangsa radikal bebas. Efek antioksidan seng berperan dalam patogenesis infeksi saluran napas. Seng dapat menurunkan akumulasi spesies oksigen reaktif saat terjadi infeksi yang dapat menyebabkan kerusakan jaringan. Seng juga berfungsi sebagai growth agent regenerasi sel epitel saluran pernapasan yang rusak akibat infeksi saluran pernapasan.

\section{DAFTAR PUSTAKA}

1. Basnet S, Mathisen M, Strand TA. Oral Zinc and Common Childhood InfectionsAn Update. J Trace Elem Med Biol. 2015;31:164-5.

2. Kusnugroho D. Peran Zink dalam Tata Laksana Pneumonia. Kalbe Medical Portal. 2013;40:427-8.

3. Kumar V, Choudhry VP. Iron Deficiency and Infection. Indian J Pediatr. 2010;77:789.

4. Tansarli GS, Karageorgopoulos DE, Kapaskelis A, Gkegkes I, Falagas ME. Iron Deficiency and Susceptibility to Infections: Evaluation of the Clinical Evidence. Eur J Clin Microbiol Infect Dis. 2013;32:1256.

5. Nelms M, Sucher K, Lacy K, Long S. Disease of the Respiratory System. In: Nutrition Therapy and Pathophysiology. 2nd ed. Belmont; 2010. p. 672.

6. Shah UH, Abu-shaheen AK, Malik MA, Alam S, Riaz M, Al-tannir MA. The Efficacy of Zinc Supplementation in Young Children with Acute Lower Respiratory Infections : A Randomized Double-Blind Controlled Trial. Clin Nutr. 2013;32(2):195.

7. Maggini S, Wintergerst ES, Beveridge S, Hornig DH. Selected Vitamins and Trace Elements Support Immune Function by Strengthening Epithelial Barriers and Cellular and Humoral Immune Responses. Br J Nutr. 2007;1:31.

8. Wolvers DAW, Herpen-broekmans W Van, Logman MHGM, Wielen RPJ Van Der, Albers R. Effect of a Mixture of Micronutrients, But Not of Bovine Colostrum Concentrate, on Immune Function Parameters in Healthy Volunteers : A Randomized Placebo-Controlled Study. Nutr Jrnl. 2006;11:5-6.

9. Agustyaningsih E. Faktor Faktor yang Berhubungan dengan Kejadian ISPA pada 
Balita Usia 1-4 Tahun di Wilayah Kerja Puskesmas Pringapus Kecamatan Pringapus Kabupaten

10. Suyami, Sunyoto. Karakteristik Faktor Risiko ISPA pada Anak Usia Balita di Puskesmas Pembantu Krakitan, Bayat, Klaten. J Helath Sci. 2006;1:14.

11. De Araujo GV, De Oliveira Junior MH, Peixoto DM, Sarinho ESC. Probiotics for the treatment of upper and lower respiratory-tract infections in children: Systematic review based on randomized clinical trials. J Pediatr (Rio J). 2015;91(5):415.

12. Taksande AM, Yeole M. Risk factors of Acute Respiratory Infection ( ARI ) in Under-Fives in a Rural Hospital of Central India. J Pediatr Neonatal Individ Med. 2016;5(1):4.

13. Richard SA, Zavaleta N, Black RE. Zinc and Iron Supplementation and Malaria, Diarrhea, and Respiratory Infections in Children in the Peruvian Amazon. 2006;(December 2017)

14. Pasricha S, Hayes E, Kalumba K, Biggs B. Eff ect of Daily Iron Supplementation on Health in Children Aged 4 - 23 Months: A Systematic Review and MetaAnalysis of Randomised Controlled Trials. Lancet Glob Heal. 2013;1(2):79.

15. Sampaio DLB, Mattos ÂP De, Cristina T, Ribeiro M, Efigênia M, Leite DQ, et al. Zinc and Other Micronutrients Supplementation Through The Use of Sprinkles: Impact on The Occurrence of Diarrhea And Respiratory Infections in Institutionalized Children. J Pediatr. 2013;89(3):290.

16. Mulyati S, Julia M, Mursyid A. Pengaruh Suplementasi Besi-Folat, Vitamin A dan Seng terhadap Durasi dan Frekuensi Sakit ISPA pada Anak Sekolah Dasar dengan Status Gizi Kurang di Kabupaten Bantul. J Gizi Klin Indones. 2007;4(1):14-5.

17. Zulaikhah ST, Soegeng P, Sumarawati T. Risk Factors of Acute Respiratory Infections in Practice Area for Community of Medical Students in Semarang. Natl Public Heal J. 2017;11(4):193.

18. Ali K, Kim RY, Mayall JR, Martin KL, Shahandeh A, Abbasian F, et al. Role of Iron in The Pathogenesis of Respiratory Disease. Int J Biochem Cell Biol. 2017;88:184-5.

19. Cassat J, Skaar E. Iron in Infection and Immunity. NIH Public Acces. 2014;13(5):2. 